\title{
Market Architecture as trigger of regional development
}

\author{
Nataliy Sidorova. $\mathrm{PhD}$. \\ Engineering school \\ Far Eastern Federal University \\ Vladivostok, Russia \\ Sidorova.n0656@yandex.ru
}

\author{
Dr. Vladimir Osipov \\ Institute of Economics of RAS \\ Moscow, Russia \\ vs.ossipov@gmail.com
}

\author{
Dr. Aleksey Zeldner, Prof. \\ Institute of Economics of RAS \\ Moscow, Russia \\ zeldner@inecon.ru
}

\begin{abstract}
The market field is formed as a result of the interaction of firms that produce a product within a single reproduction process, but at the same time, they vary in volume, quality, structure and types of capital they have. Proceeding from the fact that "architecture - the art and science of building, designing buildings and structures (including their complexes), as well as the totality of buildings and structures that create a spatial environment for human life and activity", under the architecture of markets, the authors propose to understand design and markets formation, creating a spatial, organized environment for business. The firm's behavior can consist both in expanding its market niche through improvements in its product, and in expanding the market itself by producing those products that satisfy the needs of the consumer more fully or more broadly. The main documents that determine the goals of socioeconomic development of the Far Eastern Federal District are: "Strategy of socio-economic development of the Far East and Baikal region for the period until 2025"
\end{abstract}

Keywords - architecture of markets, path dependence, markets of the Far East of Russia, territories of advanced development, State program "Socio-economic development of the Far East, of energy policies".

\section{INTRODUCTION}

The notion of the architecture of markets is put into scientific circulation by the American economist-sociologist Neil Fligstein to describe the sociological approach to the problem of the functioning of markets or market mechanisms. The market for Fligstein is an organizational field, the origins of which stem from the works of P. Bourdieu and his ideas of the structural concept of the field. The market field is formed as a result of the interaction of firms that produce a product within a single reproduction process, but at the same time, they vary in volume, quality, structure and types of capital they have (1)

\section{ORGANIZED ENVIRONMENT FOR BUSINESS}

It is quite obvious that within the framework of the reproduction process, firms of various organizational and legal forms can function. But within the organizational field, they form specific links with each other so that a so-called synergetic effect from their cooperation is formed.
It is interesting that Fligstein $[1,10,12]$ himself does not define the architecture of markets in his famous work. He takes for granted the understanding of this term by his readers. However, for example, C. Menard argues that "... the concept of the market is not as clear as it might be supposed" [2]. In this regard, it seems necessary to determine the terms for further research. Proceeding from the fact that "architecture is the art and science of building, designing buildings and structures (including their complexes), as well as the totality of buildings and structures that create a spatial environment for human life and activity", under the architecture of markets, the authors propose to understand design and markets formation, creating a spatial, organized environment for business.

This understanding allows us to explore trends in the formation of markets (spontaneous or conscious), the design of its structure, its development depending on endogenous and exogenous factors, etc.

The architecture of the markets of the Far East of Russia has its own specifics, which became possible as a result of the path dependence. It is the very fact of the manifestation of specificity that is not unique, since it becomes possible anywhere in the world under the influence of the rutting effect, but the authors are interested in exactly the specific features of the markets of the Far East for determining the trends and competitive advantages of the markets and their participants.

\section{THE DEVELOPMENT OF THE FAR EAST}

The development of the Far East was set as the main goal in connection with the adoption of the Federal Law of December 29, 2014 No. 473-FZ «On the territories of advanced social and economic development in the Russian Federation». Although in the first article of the law we are talking about the areas of advanced socio-economic development (hereinafter referred to as "TPD") irrespective of the Far East, Chapter 8 is devoted specifically to the TPDs in the Far Eastern Federal District. It is important to note that the first TPDs appeared exactly in the Far East Table 1.1 - List of 
territories of advanced development of the Far East Federal District

TABLE I. LIST OF TERRITORIES OF ADVANCED DEVELOPMENT OF THE FAR EAST FEDERAL DISTRICT

\begin{tabular}{|c|c|c|}
\hline No. & $\begin{array}{l}\text { Date of the Resolution } \\
\text { of the Government of the } \\
\text { Russian Federation on the } \\
\text { establishment of TPD }\end{array}$ & $\begin{array}{l}\text { The name of the TPD on the } \\
\text { basis of the Decree of the } \\
\text { Government of the Russian } \\
\text { Federation }\end{array}$ \\
\hline 1 & 25th of June 2015 & $\begin{array}{l}\text { On the creation of the territory of } \\
\text { the advanced socio-economic } \\
\text { development "Nadezhdinskaya" } \\
\text { (Primorsky Krai) }\end{array}$ \\
\hline 2 & 25th of June 2015 & $\begin{array}{l}\text { On the creation of the territory of } \\
\text { advanced socio-economic } \\
\text { development "Komsomolsk" } \\
\text { (Khabarovsk Krai) }\end{array}$ \\
\hline 3 & 25th of June 2015 & $\begin{array}{l}\text { On the creation of the territory of } \\
\text { the advanced socio-economic } \\
\text { development "Khabarovsk" }\end{array}$ \\
\hline 4 & 25th of June 2015 & $\begin{array}{l}\text { On the creation of the territory of } \\
\text { the advanced social and economic } \\
\text { development "Priamurskaya" (Amur } \\
\text { Region) }\end{array}$ \\
\hline 5 & 25th of June 2015 & $\begin{array}{c}\text { On the creation of the territory of } \\
\text { advanced social and economic } \\
\text { development "Belogorsk" (Amur } \\
\text { Region) }\end{array}$ \\
\hline 6 & 25th of June 2015 & $\begin{array}{l}\text { On the creation of the territory of } \\
\text { the advanced social and economic } \\
\text { development "Mikhailovskiy" } \\
\text { (Primorsky Krai) }\end{array}$ \\
\hline 7 & 25th of June 2015 & $\begin{array}{l}\text { On the creation of the } \\
\text { territory of advanced social and } \\
\text { economic development } \\
\text { "Beringovsky" (Chukotka } \\
\text { Autonomous District) }\end{array}$ \\
\hline 8 & 25th of June 2015 & $\begin{array}{l}\text { On the creation of the territory of } \\
\text { the advanced social and economic } \\
\text { development "Industrial Park" } \\
\text { Kangalassy "(Republic of Sakha } \\
\text { (Yakutia)) }\end{array}$ \\
\hline 9 & 25th of June 2015 & $\begin{array}{l}\text { On the creation of a territory for } \\
\text { advanced social and economic } \\
\text { development "Kamchatka" } \\
\text { (Kamchatsky Krai) }\end{array}$ \\
\hline
\end{tabular}

The previously mentioned Chapter 8 of the Federal Law on TPDs states: "Chapter 8. On the peculiarities of the establishment and functioning of the institutes for the development of the Far East, as well as certain measures of state support for the constituent entities of the Russian Federation that are part of the Far Eastern Federal District

As the outstanding futurist Alvin Toffler correctly notes: "The market does not consist only of steel or shoes, cotton or canned goods. The market is the structure through which goods and services move. Moreover, this is not just an economic structure. This is a way of organizing people, a way of thinking, this is a certain set of expectations (it expectation that certain goods will actually be delivered). Thus, the market is not only an economic reality, but also a psychological structure. Therefore, its influence goes far beyond the economy."

Since the architecture of the market is tightly connected with the organizational field, and within the framework of our research the institutional conditions of the Far East are of importance, one should turn to the data of state statistics and estimate the demography of firms in the region. For these purposes, let us propose to consider the data on the fertility and official liquidation rates per 1000 organizations [7,8].

It is necessary to look for a certain balance between interfarm relations regarding the distribution of property rights and anti-market alliances. It is important to note that such balance within the framework of TPDs can be found by means of reciprocal reconciliation of mutual interests by residents of TPDs within the framework of the reproduction process. In addition, markets are not a fixed structure, as their architecture is constantly changing depending on the number of participants in the economic relations, the quality (consumer) and price characteristics of the goods, as well as the barriers to entry into the market. For example, the air transportation market has high entry barriers, as it requires huge financial resources for buying / leasing / leasing the fleet, as well as hiring personnel, while the tutoring market has low entry barriers, as it is enough to have the knowledge to start this activity. Of course, the number of market participants is of great importance, since a large number of them speak of a highly competitive market, where achievement of the aboveaverage profit indicators involves a search for a complex strategy $[9,11,13]$.

The converse is just as true, a small number of firms on the market testify to the possibility of obtaining higher profits with less effort. Finally, probably most important is related to the quality (consumer) and price characteristics of the goods. Price characteristics are important in markets where there is a large number of producers of identical products and competition is possible, in practice, only at a price. Qualitative (consumer) characteristics of the goods are, de facto, the only factor controlled by the firm that can be realized by the producer within the internal environment. It is here that the possibility of competitive gains and high levels of profit margins lies. The firm's behavior can consist both in expanding its market niche through improvements in its product, and by expanding the market itself by producing those products that satisfy the needs of the consumer more fully or more broadly.

Within the framework of TPD, this strategy is expressed in that it is not a mass product already available on the market that is produced, but either an improved or completely new product that can more fully satisfy the needs of the consumer. As part of our study, we made an attempt to justify the need for innovative character of the activities of the TPD residents as an important factor in the success of the TPD projects themselves. Infrastructure support of the Far East is of paramount importance for the development of TPD as territorial agglomerations of their residents. Today, the economy of the Far East has an export-raw-material orientation and is characterized by the non-competitiveness of 
its processing sector. To change the existing situation, the state implements major investment projects aimed at creating a modern infrastructure, modernization and further development of which will become an incentive and a reliable base for attracting investments in industry and other branches of the Far East [5, 15].

The natural and climatic conditions of the Far East are characterized as very severe and even extreme. Only in the south of the Primorsky Krai, the average annual temperature exceeds the zero mark, so the reliable supply of enterprises and the population of the Far East in the autumn-winter period with electric and thermal energy is vital. This significantly increases the paramount importance of energy for the social and economic development of the Far Eastern Federal District.

The main documents that determine the goals of socioeconomic development of the Far Eastern Federal District are:

"Strategy of socio-economic development of the Far East and the Baikal region for the period until 2025" (approved by the RF Government Decree No. 2094-r on 28.12.2009);

State program "Socio-economic development of the Far East and the Baikal region for the period until 2025" (approved by the RF Government Decree No. 466-r of 29.03.2013).

According to these documents, the main goal of social and economic development is "Realization of the geopolitical task of securing the population in the Far East and Baikal region due to the formation of a developed economy and a comfortable human environment in the subjects of the Russian Federation located on this territory, as well as the achievement of the average Russian level of socio- Economic development". This goal setting contributes to the solution of the problem of "keeping the population at the expense of increasing the level of social support and strengthening the coherence of the territories through the construction of expensive infrastructure facilities (primarily transport)" [5,6,14].

Positive dynamics of socio-economic development of the Far Eastern Federal District from 2008-2012. Based on significant, growing volumes of investment in the fixed capital of the Far Eastern Federal District and budget support for various sectors of the economy. The main areas of investment in the Far Eastern Federal District are transport and communications $(35.2 \%)$ and mining $(23.6 \%)$, which is due to the specifics of the region's social and economic development. About $80 \%$ of investments in the fixed capital of the Far Eastern Federal Districts fall on four regions: the Republic of Sakha (Yakutia), Primorsky Krai, the Khabarovsk Territory and the Sakhalin Region. The basis of the region's economy in this period was the implementation of large-scale investment projects within the framework of federal target programs (APEC summit, etc.), the construction of pipeline transport facilities by state companies and the development of new mineral deposits, which led to an increase in the imbalance in the Far Eastern District economy in the direction of further increasing the share of production Mineral resources in the GRP region and the active development of the construction industry. And although the Far Eastern region has a rich resource base with high energy reserves, such forecasts of socio-economic development require mandatory development of energy policies and management decisions in the field of energy efficiency.

Today, the basis for the development of the region is the law on the territories of advanced development.

The Government of the Russian Federation decides to create a territory for advanced social and economic development for seventy years on the basis of a proposal from the authorized federal body (Ministry of the Russian Federation for the Development of the Far East). This decision is made in the form of a resolution (Decree of the Government of the Russian Federation No. 628 of June 25, 2015 "On the Establishment of the Territory for Advanced Socio-Economic Development" Komsomolsk "), which provides:

- A list of types of economic activities, in the implementation of which a special legal regime for the performance of business activities is provided for by this Federal Law;

- The minimum volume of capital investments of residents of the territory of advanced socioeconomic development in the implementation of relevant types of economic activity in the territory of advanced social and economic development;

- The provision on the application or non-use in the territory of the advanced social and economic development of the customs procedure of the free customs zone established by the customs legislation of the Customs Union;

- Description of the location of the boundaries of the territory of advanced social and economic development;

- If necessary, minimum requirements to the level of advanced socio-economic development applied by residents for the use of technologies and methods of production, equipment for relevant economic activities.

The Ministry of the Russian Federation for the Development of the Far East implements:

- Issuance of construction permits, permits to commission facilities for the construction and reconstruction of infrastructure facilities of the advanced socio-economic development area, with the exception of the facilities specified in clause 5.1 of part 1 of Article 6 of the City Construction Code of the Russian Federation, except for highways of federal significance;

- Coordination of the territorial planning scheme of the subject of the Russian Federation in which a TPD is created;

- Coordination of documentation on the planning of TPD for the location of capital construction facilities of regional importance within the boundaries of the municipality where TPDs are located, the implementation of state construction supervision in cases provided for by the Town Planning Code of the Russian Federation;

- Approval of the draft plan for the TPD for its integrated development; 
- Approval of the procedure for keeping the register of residents;

- Control over the fulfillment by the resident of the territory of the advanced social and economic development development agreement on the implementation of activities;

- Control over the activities of the management company and its subsidiary;

- Coordination of documents of territorial planning of municipalities within which the territory of advanced social and economic development is located, as well as land use and development rules;
- Provision of land plots that are in federal ownership and located on the TPD;

- Decision on reservation of land and compulsory alienation of land plots (withdrawal of land plots) for state needs in order to locate infrastructure facilities for the territory of advanced social and economic development, establishment of easements in relation to land for the purpose of locating the infrastructure of TPD;

- Consideration of complaints about refusal to conclude an Agreement on the implementation of activities.

TABLE II. INFORMATION ON THE CURRENT BENEFITS AND PREFERENCES FOR RESIDENTS OF THE TPD

\begin{tabular}{|c|c|c|c|c|c|}
\hline & Type of Tax & \begin{tabular}{|c|} 
Tax rate \\
without \\
consideration of \\
benefits
\end{tabular} & $\begin{array}{c}\text { Tax rate with regard to benefits } / \\
\text { preferences }\end{array}$ & $\begin{array}{l}\text { Duration of } \\
\text { benefits }\end{array}$ & $\begin{array}{l}\text { The basis of the benefits / } \\
\text { preferences }\end{array}$ \\
\hline 1 & $\begin{array}{ll}- & \text { Income } \\
- & \text { Taxes } \\
- & \text { Federal } \\
- & \text { Regional }\end{array}$ & $20 \%$ & $\begin{array}{l}0 \% \text { in the first } 5 \text { years from the } \\
\text { moment of income getting ( } 2 \% \text { - } \\
\text { Federal, } 10 \% \text { - Regional) }\end{array}$ & 10 years & $\begin{array}{l}\text { Second Part of Tax Code of } \\
\text { the Russian Federation }\end{array}$ \\
\hline 2 & $\begin{array}{l}\text { Corporate property } \\
\quad \operatorname{tax}\end{array}$ & $2,2 \%$ & $\begin{array}{c}0,5 \% \text { in the first } 5 \text { years, } 1,1 \% \text { - in } \\
\text { the second } 5 \text { years from the business } \\
\text { beginning of the resident }\end{array}$ & 10 years & $\begin{array}{l}\text { Second Part of Tax Code of } \\
\text { the Russian Federation }\end{array}$ \\
\hline 3 & $\begin{array}{l}\text { Deductions for } \\
\text { social needs }\end{array}$ & $30 \%$ & $\begin{array}{c}7,6 \% \\
\text { - } \quad \begin{array}{c}\text { Pension Fund of the Russian } \\
\text { Federation 6\%; }\end{array} \\
\text { - Fund of Social Insurance of } \\
\text { the Russian Federation 1,5\%; } \\
\text { - Federal Fund of the } \\
\text { Obligate Medical Insurance } 0,1 \%\end{array}$ & 10 years & $\begin{array}{c}\text { Federal Law of 24th July } \\
\text { 2009 No 212- FZ «On insurance } \\
\text { contributions to the Pension Fund } \\
\text { of the Russian Federation, the } \\
\text { Social Insurance Fund of the } \\
\text { Russian Federation, the Federal } \\
\text { Compulsory Medical Insurance } \\
\text { Fund» }\end{array}$ \\
\hline
\end{tabular}

\section{CONCLUSION}

Based on the presented list, it is possible to justify the sectoral orientation of the development of the region and enterprises for localization within the framework of the implementation of the basic development strategy at the TPD stage.

\section{References}

[1] N. Fligstein. The Architecture of Markets. Economic Sociology of Twenty-First-Century Capitalistic Societies. Moscow, HSE, 2013.
[2] C. Menard. L'economie des Organisations. Moscow, INFRA-M. P. 25, 1996.

[3] Architecture. New Illustrated Encyclopedia. Book Moscow, Bolshaya Rossijskaya Enciclopedia., p. 256, 2002.

[4] A. Toffler. The Third Wave. Moscow, AST. p.461, 2004.

[5] V. Osipov, T. Skryl, "The strategic directions of the modern Russian economic development." International Business Management. Vol. 10. \# 6. P. 710-717, 2016.

[6] M.E. Kosov, R.G. Akhmadeev, V.S. Osipov, Yu.K. Kharakoz, I.I. Smotritskaya, "Socio-Economic Planning Of The Economy." Indian Journal of Science and Technology, Vol. 9, № 36, P. 102-008, 2016.

[7] V.S. Osipov, Project-Functional Structure of Management for Public Administration. Public Administration Issue, n.3, pp.219-230, 2016. 
[8] S.N. Silvestrov, A.G. Zeldner, V.S. Osipov, "Introduction to the Theory of Economic Dysfunction," Mediterranean Journal of Social Sciences, Vol. 6, № 3, pp. 394-399, 2015

[9] V. S. Osipov, T.V. Skryl, E.A. Blinova, M.E. Kosov, A.G. Zeldner, A.N Alexeev, Institutional Analysis of Public Administration System, Volume 15, Number 15, pp.192-203, 2017.

[10]N. N. Fligstein, D. McAdam, A Theory of Fields. Oxford University Press, 2012.

[11]J. Beckert, M. Dewey, The Architecture of Illegal Markets. Towards an Economic Sociology of Illegality in the Economy. Oxford University Press, 2017.

[12]W. Powell, P. J. DiMaggio, The New Institutionalism in Organizational Analysis. The University of Chicago Press, 1991.

[13]K. Mason, M. Friesl, C. J. Ford, Managing to make markets: Marketization and the conceptualization work of strategic nets in the life science sector. Industrial Marketing Management, In press, corrected proof, Available online 19 July 2017 http://www.sciencedirect.com/science/article/pii/S0019850117305023

[14]P. Syrpis, The Judiciary, the Legislature and the EU Internal Market. Cambridge University Press, 2012.

[15]S. H. Axilrod, Transformation of Markets and Policy Instruments for Open Market Operations. Working Paper. International Monetary Fund, 1995. 